\title{
Specific Nature of the Biochemical Composition of Spruce Wood from the Forest Stands Exposed to Drying out in European Russia
}

\author{
Konstantin VEDERNIKOV*@, Egor ZAGREBIN@, Irina BUKHARINA@ \\ Udmurt State University, Izhevsk, RUSSIAN FEDERATION \\ *Corresponding Author: vedernikov.usu@bk.ru
}

Received Date: 25.01.2020

Accepted Date: 28.05 .2020

\section{Abstract}

Aim of study: The paper presents the results of studying the content of extractive substances in Picea obovate L. wood in places of mass development of Ips typographus in the European part of Russia (the Udmurt Republic).

Area of study: The Udmurt Republic is located in the East of the Eastern European plain (in the Urals) and has the total area of 42.1 thousand $\mathrm{km}^{2}$. Udmurtia is located in the basins of such large rivers as the Kama and Vyatka.

Material and methods: To assess forest stands, two test plots were allotted in two forest districts in the South of the Republic. Stand parameters of the plantings were determined according to generally accepted methods. After taking into account all the trees on the site, the plants of the main tier were divided into three groups according to their vital condition. Within each group, three individuals were selected to study the biochemical characteristics of wood.

Main results: The results of the study showed that one of the factors determining the content of extractive substances is the state of the plant.

Highlights: It is obvious that the studied substances play an important protective role in the adaptive reactions of Siberian spruce in response to bark beetles.

Keywords: The Death of Coniferous, Ips typographus, Picea obovata, Extractives, Stability, Resin

\section{Avrupa Rusyası'nda Kurumaya Maruz Kalan Orman \\ Meşcerelerinden Alınan Ladin Ağacının Biyokimyasal Bileşiminin Özgün Doğası}

$\ddot{O} \mathbf{z}$

Çalışmanın amacı: Makale, Rusya'nın Avrupa kısmındaki (Udmurt Cumhuriyeti) Ips typographus'un kitlesel gelişim yerlerinde, Picea obovate L. odununda bulunan ekstraktif maddelerin içeriğini incelemektedir.

Çalışma alanı: Udmurt Cumhuriyeti, Doğu Avrupa Platosu'nun doğusunda (Urallar'da) yer almakta ve yüzölçümü 42.1 bin $\mathrm{km}^{2}$ 'dir. Aynı zamanda, Kama ve Vyatka gibi büyük nehirlerin havzalarında yer almaktadir.

Materyal ve yöntem: Orman meşcerelerini değerlendirmek için, Udmurt Cumhuriyet'in güneyindeki iki orman bölgesinde iki deneme alanı tahsis edilmiştir. Meşçere parametreleri genel kabul görmüş yöntemlere göre belirlenmiştir. Sahadaki tüm ağaçlar dikkate alınarak ana kanopi bitkileri yaşamsal durumlarına göre üç gruba ayrılmıştır. Her gruptan, ahşabın biyokimyasal özelliklerini incelemek için üç birey seçilmiştir.

Temel sonuçlar: Çalışmanın sonuçları, bitki durumunun ekstraktif maddelerin içeriğini belirleyen faktörlerden biri olduğunu göstermiş̧tir.

Araştırma vurgulart: İncelenen maddelerin, kabuk böceklerine tepki olarak Sibirya ladininin adaptif tepkilerinde önemli koruyucu bir rol oynadığı açıkça belirlenmiştir.

Anahtar Kelimeler: İğne Yapraklıların Ölümü, Ips typographus, Picea obovata, Ekstraktifler, Sağlamlık, Reçine. 


\section{Introduction}

Dying of the woods in Russia has been known since the $19^{\text {th }}$ century, with its periodic occurrence, and was largely associated with the adverse weather conditions. Nonetheless, as far back as at the end of the $20^{\text {th }}$ century, the extensive drying up of forests in Russian emerged on a cascading dynamics spreading progressively into many regions, and developing at the scale of an environmental disaster.

This process is very fast moving, and covers almost all regions of the European part of Russia. The scattered foci of spruce drying are detected in Leningrad, Novgorod, Pskov regions and in Karelia; besides, they were found in the regions of Moscow, Bryansk, and Kaluga (Zhigunov et al., 2007; Alyab'ev, 2013). Deterioration of the forests condition is observed not only in Russia, but also in Eastern and Western Europe (Fedorov \& Sarnackij, 2005; Leontovyc \& Kunca, 2006; Caudullo et al., 2016), including such island countries as Ireland and Great Britain (Tuffen \& Grogan, 2019). The mass death of coniferous forest is also common in the continent of North America (Negrón, 2018). These instances confirm not only the transboundary scale, but rather the global nature of the ongoing processes.

The primary reason for the dry-out of plantations is representative of the unfavorable natural climatic conditions, which cause weakening of the protective mechanisms in plants and, at times, their death. This contributes to the activation and spread of pathogenic organisms. Thus, the hot weather conditions of 2010 in the European part of Russia resulted in weakening of coniferous stands, when the spruce stands with their superficial root system suffered to a greater extent. All this triggered an outbreak of mass reproduction of coniferous forest pests, i.e. Ips typographus.

It is noteworthy that the key cause of death of European spruce represents the reproduction of bark beetles in connection with windfalls or evolution of other pathogens. Nonetheless, owing to the global climate change, there was a buildup in frequency of summer droughts and heat waves (Kennel \& Yulaeva, 2020). This, in turn, affected the wind factor being the main cause of death in spruce. In Central Europe, the mass death of Scots pine from spruce bark beetle turned to be a relatively new phenomenon, and came as a surprise to many forest owners, particularly because pine is believed to be a relatively drought-resistant species (Kunert, 2020).

In this regard, the important issue lies is studying the response of plants to pest invasion. Extraneous substances with high biological activity have a crucial protective function in coniferous wood, and which are produced to serve as protective compounds in the course of plant life. The production of these substances are complex processes, and change under influence of the external factors. Pursuant to the previous studies, the structure of wood and its chemical composition change depending on the habitat, particular characteristics of individuals, and sampling locations (Scheffer \& Cowling, 1966; Fedorova et al., 2016).

The aim of the paper was to study the chemical composition of spruce wood in individuals at different life states in areas of active reproduction of spruce bark beetles.

\section{Material and Methods}

The research was conducted on the territory of the Udmurt Republic (hereinafter UR). The Republic is located in the East of the Eastern European plain (in the Urals). The total area of Udmurtia is 42.1 thousand $\mathrm{km} 2$. Udmurtia is located in the basins of such large rivers as the Kama and Vyatka.

With its considerable elongation in the north-south direction $(320 \mathrm{~km})$ and the hillyridged terrain of the landform, the Republic experiences significant differences in temperature, humidity, wind conditions, and depth of precipitation between its northern and southern parts. Hence, the territory of Udmurtia is geographically located within two landscape zones: taiga (boreal) and subtaiga (boreal-subboreal). As per the forest vegetation zoning, the two forest regions are identified in the territory of the Republic: the southern taiga region of the European part of the Russian Federation (in the north), and coniferous-deciduous (mixed) forests of the European part of the Russian Federation (in the south) (Figure 1) (Rysin, 2009). 
In Udmurtia, two ranges of the spruce species border: European spruce (Picea abies (L.) Karst) and Siberian spruce (Picea obovata Ledeb.). There is also an outstanding hybrid, i.e. Finnish spruce (Picea fennica
(Regel) Kom.). Studying the morphological characters in macrostrobil biogroups, the authors were able to identify the species representing the genus Picea.

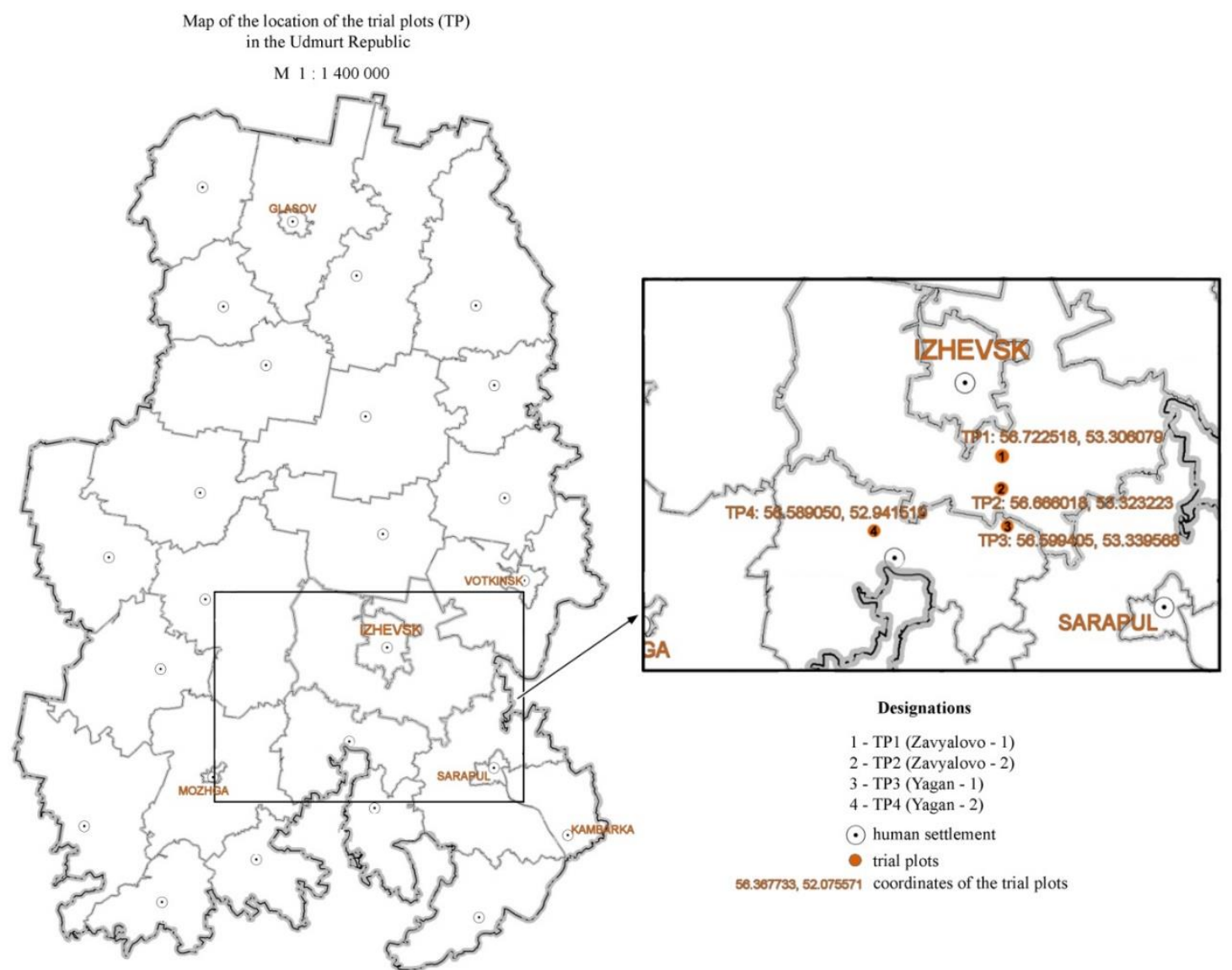

Figure 1. Location map of the test plots in the Udmurt Republic

In spruce-oxalis forests in the territory of two forest districts (Zavyalovo and Yagan) located in the subtaiga zone (borealsubboreal/coniferous-deciduous forest zone), there were secured three test plots (of 1 hectare in size). The choice of these sites as test plots was done through decoding of the available space images (Yandex Maps, with the use of the SAS.Planet and MapInfo Professional software programs) and by specifying their position in-situ during visits with the required consideration of the localized areas of spruce drying out. The test plots were mapped out by specifying their geographic coordinates by means of Garmin etrex 30 GPS navigator and converting them in decimals.
The enumeration survey of the forest taxation was employed in test plots. From 154 to 441 individuals were examined in each test plot, with the diameter of the trees measured by calipers (manufactured by Taxator LLC, Russia), their age by Haglof$350 \mathrm{~mm}$ age drill (manufactured by Haglof, Sweden), their height by Forestry Pro Nikon altimeter (manufactured by Nikon, China). The soils in test plots were sod-podzolic, and loamy in granulometric composition.

The main taxation parameters of the stand (composition of species, average diameter $\left(D_{\mathrm{av}}, \mathrm{cm}\right)$, average height $\left(\mathrm{H}_{\mathrm{av}}, \mathrm{m}\right)$, average age $\left(A_{a v}\right.$, years $)$, density $\left(\Sigma G, \mathrm{~m}^{2} / \mathrm{ha}\right)$, and stock of dead wood $\left(\mathrm{M}, \mathrm{m}^{3}\right)$ were determined as per the generally accepted methods (Scheffer et al., 1998). The productivity of 
trees and plantings in general was determined by assigning each measured tree to the category of Class in line with the average stand diameter: Class I-1.46 and higher, Class II-1.45 ... 1.16, III-1.15 ... 0.86, IV0.85 ... 0.76, Class V-0.75 and lower.

The trees were split into the following groups according to their life state: 1) good (the crown is thick or slightly sparse, the needles are green/light green); 2) satisfactory (openwork crown; needles light green, there are traces of bark beetle damage); 3) unsatisfactory vitality (crown strongly openwork; needles from yellow-green to redbrown; growth is very weak or absent; shrinkage of more than $2 / 3$ of the branches, the bark is partially opal).

In October, which coincides with the end of the growing season in conifers growing in the temperate zone, the wood samples were taken exclusively from the individuals of Siberian spruce (Picea obovata Ledeb.). The selection was done separately as regards the individuals of good, satisfactory and unsatisfactory condition. The wood samples were cut by Haglof $-350 \mathrm{~mm}$ age drill at the height of $0.3 \mathrm{~m}$ from the root neck of the tree. Preparation of samples for biochemical analysis comprised as follows: air dry treatment, grinding, sieving through a sieve with a $0.5 \mathrm{~mm}$-diameter mesh. The particles that did not pass through the sieves were not involved into the biochemical analyzes of wood (Obolenskaya et al., 1991).

The biochemical analyses were carried out at the laboratory of the Federally Funded Educational Institution of Higher Education Udmurt State University (Izhevsk). Coniferous extractives were fractionated in accordance with their chemical nature by sequential extraction with solvents of increasing polarity. The extractives were identified using hot distillation in a Soxhlet apparatus, i.e. water-soluble substances with hot water, resinous substances with alcoholtoluene mixture. The tannin content in the solution was determined using PE-5400UF spectrophotometer (spectrophotometer PE5400 UF, 200.04.031, EKROSKHIM, Russia) at a wavelength of $277 \mathrm{~nm}$ (Babkin, 2017). In order to identify the destructive fungi, some wood underwent a series of dilutions by rice agar and Czapek's medium (Bahshaliyeva, 2017). Identification of fungi was performed by means of the determinants (Kirk et al., 2008; Sutton et al., 2001).

The sample wood of unsatisfactory condition was analyzed for the degree of decomposition caused by mycodestructors by absorbing a $1 \%$ sodium hydroxide solution $(\mathrm{NaOH})$ (TAPPI, 1993).

Sample variance analysis was used to estimate the significance of sample differences using the Duncan multi-rank test (Lakin, 1990). Mathematical processing of the results and visualization of the data was performed by means of the statistical analysis with the environment R (Mastickij, 2015). The cluster analysis was performed using the Statistica 6.0 package of the statistical software.

\section{Results}

\section{Taxation Characteristics}

In view of the forest productivity, in Zavyalovo forestry the forest stands can be attributed to Class III $(31-57 \%$ of the recorded trees), and to Class IV of highly productive in Yagan forestry $(53 \%$ of trees from the $1^{\text {st }}$ test plot were assigned to Classes IV-V; and $74 \%$ trees of Class I were absent in the $2^{\text {nd }}$ test plot). The dead individuals mostly belonged to Classes I-II. Thus, the low productivity of the forest stands is linked with dying out of larger individuals, which ultimately resulted in lower levels of the stand density.

The studied forest stands are assigned to a maturing age group (61-80 years old), which is characterized by the greatest increases in height and diameter. It was revealed that Ips typographus is likely to damage more often the individuals aged 70-90 years in Russia. Since this is the age when the spruce stands suffer most from the effects of drought. This is due to the well-developed aboveground mass and superficial root system of plants (Maslov, 2010).

The average taxation characteristics of the stands on the studied TP are presented in Table 1. 
Table 1. Average taxation characteristics of stands on test plots (Government of the Udmurt Republic, 2019)

\begin{tabular}{|c|c|c|c|c|c|c|c|c|c|c|c|}
\hline \multirow[b]{2}{*}{$\begin{array}{l}\text { Test } \\
\text { plots }\end{array}$} & \multirow{2}{*}{$\begin{array}{l}\text { Forest district, } \\
\text { coordinates of the } \\
\text { test plots }\end{array}$} & \multirow[b]{2}{*}{ Composition* } & \multirow{2}{*}{$\begin{array}{l}\text { Quantity } \\
\text { of trees } \\
\text { on TP }\end{array}$} & \multirow{2}{*}{$\begin{array}{c}\text { Percentage } \\
\text { of } \\
\text { deadwood, } \\
\% \\
\end{array}$} & \multirow{2}{*}{$\begin{array}{c}\mathrm{A}_{\mathrm{av} .} \pm \sigma \\
\text { years }\end{array}$} & \multirow{2}{*}{$\begin{array}{c}\mathrm{H}_{\mathrm{av} . .} \pm \sigma \\
\mathrm{m}\end{array}$} & \multirow{2}{*}{$\begin{array}{l}\mathrm{D}_{\mathrm{av} .1,3} \pm \sigma \\
\quad \mathrm{cm}\end{array}$} & \multicolumn{2}{|c|}{$\sum \mathrm{G}, \mathrm{m}^{2} / \mathrm{ha}$} & \multicolumn{2}{|c|}{$\mathrm{M}, \mathrm{m}^{3} / \mathrm{ha}$} \\
\hline & & & & & & & & $\begin{array}{l}\text { Growing } \\
\text { wood** }\end{array}$ & $\begin{array}{c}\text { Deadwood } \\
\text { *** }\end{array}$ & $\begin{array}{l}\text { Growing } \\
\text { wood }\end{array}$ & $\begin{array}{c}\text { Deadwood } \\
* * * *\end{array}$ \\
\hline 1 & $\begin{array}{c}\text { Zavyalovo } \\
(56.722518, \\
53.306079)\end{array}$ & $\begin{array}{c}9 \mathrm{~S} 1 \mathrm{~F}+\mathrm{B} \\
90 \% \text { spruce } \\
10 \% \text { fir, } 5 \% \text { birch }\end{array}$ & 260 & 47,7 & $70 \pm 2,3$ & $21 \pm 0,6$ & $27,9 \pm 0,4$ & 10,7 & 4,2 & 107 & 67 \\
\hline 2 & $\begin{array}{c}\text { Zavyalovo } \\
(56.666018, \\
53.323223)\end{array}$ & $\begin{array}{c}9 \mathrm{~S} 1 \mathrm{~F}+\mathrm{B} \\
90 \% \text { spruce, } \\
10 \% \text { fir, } 5 \% \text { birch }\end{array}$ & 324 & 38,3 & $67 \pm 3,8$ & $23 \pm 0,6$ & $26,0 \pm 0,3$ & 11,1 & 6,8 & 120 & 88 \\
\hline 3 & $\begin{array}{c}\text { Yagan }(56.599405 \\
53.339568)\end{array}$ & $\begin{array}{c}10 \mathrm{~S} \\
100 \% \text { spruce, } 5 \% \text { fir }\end{array}$ & 252 & 50,8 & $60 \pm 1,3$ & $18 \pm 0,5$ & $25,9 \pm 0,8$ & 6,0 & 10,6 & 53 & 94 \\
\hline 4 & $\begin{array}{c}\text { Yagan }(56.589050, \\
52.941519)\end{array}$ & $\begin{array}{c}10 \mathrm{~S} \\
100 \% \text { spruce }\end{array}$ & 155 & 56,1 & $65 \pm, 1,6$ & $22 \pm 0,3$ & $21,4 \pm 0,4$ & 2,9 & 3,0 & 31 & 29 \\
\hline
\end{tabular}

Note: $\quad *-$ S (spruce), F (fir), B (birch)

** - density of plantings (in this case, the cross-sectional area of the trunk at a height of $1.3 \mathrm{~m}$ );

*** - density of dead trees (in this case, the cross-sectional area of the trunk at a height of $1.3 \mathrm{~m}$ );

**** - stock of dead wood in the trial plot. 
The results of the study revealed large reserves of dead wood. Depending on the registered area, the dead wood stock ranges from 31.1 to $93.8 \mathrm{~m} 3 / \mathrm{ha}$. Such areas, which have large reserves of dead biomass, are dangerous hotspots in forest ecosystems.

The disappearance of the dominant composition led to a change in the species composition of grasses. Forest grasses began to be replaced by field grasses. Field grasses, in turn, begin to form a dense sod that prevents the germination of spruce seeds.

In this regard, we did not find seedlings and undergrowth of spruce on the accounting sites. As undergrowth, a large number of birch trees were identified (Betula pendula Roth.), which begins to form the main tier. In the temperate zone, Betula pendula Roth. as a pioneer species, replaces conifers in the natural growth environment of the latter. This has a negative impact on the forest industry due to the fact that coniferous wood is valued higher.

In the course of research carried out in the test plots under the conditions of localized forest stands exposed to drying out, the individuals of Siberian spruce were assessed as being in a good vital condition. Just a few of them were spotted for bark beetle emergence holes on their trunks; still the overall condition of such plants (as per the external morphological characteristics) was good. In such individuals, the abundant resin flowing was recorded in places of damage. Undoubtedly, the damage and death of some individuals and the good condition of others depends on particular physiological and biochemical characteristics of wood and other organs.

\section{Extractives Content}

The degree of wood decomposition caused by filamentous fungi predetermines the content of extractives in wood. In order to exclude the impact from this factor while studying the biochemical composition of wood, only the vital condition of trees and wood destruction indicators were accounted for. The individuals showing an unsatisfactory vital condition with a high level of wood destruction (old dry wood) and possessing internal voids in the trunk were discarded. The solubility of sodium hydroxide in wood samples was recorded at 12.3 to $16.7 \%$ which corresponds to the wood with little destruction (TAPPI, 1993).

A comparative study of various extractive substances content in wood in the three selected spruce groups revealed statistically significant differences in all cases $(\mathrm{p}<0.05)$; the 'water-soluble extractive substances' was the exception group with the value of $p>0.05$. According to the results of the Duncan multirank test, the main differences between the groups are determined by the level of resins and tannins in trees at a satisfactory and unsatisfactory state $(\mathrm{p}<0.05)$. High content of all groups of extractive substances was observed in individuals of satisfactory condition, the lowest in dead individuals (Figure 2).

The results of the research showed that the total content of extractive substances, water-soluble substances and tannins is statistically significant only for the accounting areas of Yagan forestry District ( $p$ <0.05). Particularly in these test plots, extensive dying out of spruce was observed. No significant differences were found in other areas.

The results of the cluster and dispersion analyses revealed that the content of extractive substances in wood is more influenced by the state of the plant $(\mathrm{P}<0.05)$ than its immediate habitat $(\mathrm{P}>0.05)$. This phenomenon can be explained by homogeneous vegetation conditions, since TPs were secured in the same forest stands with similar reaction of plants to bark beetle infestation (Figure 3 and 4). Generally, dispersion analysis of the content of extractive substances of wood showed a low interaction of factors such as the state of plants of the place of growth. 
Table 2. The content of extractives in the wood of Picea obovata L. in different life states (Government of the Udmurt Republic, 2019)

\begin{tabular}{|c|c|c|c|c|c|c|c|c|c|c|c|c|c|}
\hline \multirow{2}{*}{\multicolumn{2}{|c|}{$\begin{array}{l}\text { Forest district, } \\
\text { coordinates of } \\
\text { No. the test plots }\end{array}$}} & \multicolumn{3}{|c|}{ The total content of extractives, $\%$ of sample } & \multicolumn{3}{|c|}{$\begin{array}{c}\text { The content of water-soluble extractives, } \% \\
\text { of sample }\end{array}$} & \multicolumn{3}{|c|}{ The content of tannins, $\%$ of sample } & \multicolumn{3}{|c|}{$\begin{array}{l}\text { The content of resinous extractives, } \\
\% \text { of sample }\end{array}$} \\
\hline & & Good & Satisfactory & Unsatisfactory & Good & Satisfactory & Unsatisfactory & Good & Satisfactory & Unsatisfactory & Good & Satisfactory & Unsatisfactory \\
\hline \multirow[b]{2}{*}{1} & \multirow{2}{*}{$\begin{array}{l}\text { Zavyalovo } \\
(56.722518, \\
53.306079)\end{array}$} & $\underline{8.41 \pm 0.40}$ & $\underline{16.78 \pm 0.10}$ & $\underline{9.91 \pm 1.74}$ & $\underline{7.20 \pm 0.20}$ & $\underline{6.62 \pm 0.09}$ & $\underline{7.57 \pm 1.58}$ & $\underline{6.63 \pm 0.33}$ & $\underline{5.83 \pm 0.08}$ & $\underline{4.06 \pm 1.35}$ & $\underline{1,21 \pm 0.24}$ & $\underline{0.16 \pm 0.01}$ & $\underline{2.33 \pm 0.20}$ \\
\hline & & $8.23-8.58$ & $\overline{16.37-17.19}$ & $2.43-17.38$ & $6.33-8.06$ & $6.22-7.02$ & $0.79-14.36$ & & $\overline{5.67-5.99}$ & & $\overline{0.17-2.25}$ & $\overline{0.15-0.16}$ & $\overline{1.47-3.19}$ \\
\hline \multirow[b]{2}{*}{2} & \multirow{2}{*}{$\begin{array}{l}\text { Zavyalovo } \\
\text { (56.666018, } \\
53.323223)\end{array}$} & $\underline{12.98 \pm 0.18}$ & $\underline{17.04 \pm 1.02}$ & $\underline{7.83 \pm 1.28}$ & $\underline{10.25 \pm 0.14}$ & $\underline{11.93 \pm 0.57}$ & $\underline{6.63 \pm 1.26}$ & $\underline{6.06 \pm 0.85}$ & $\underline{5.83 \pm 0.08}$ & $\underline{4.05 \pm 1.34}$ & $\underline{2.74 \pm 0.04}$ & $\underline{5.11 \pm 1.59}$ & $\underline{1.20 \pm 0.28}$ \\
\hline & & $\overline{12.20-13.77}$ & $\overline{12.65-21.42}$ & $\overline{2.32-13.33}$ & $\overline{9.63-10.87}$ & $\overline{9.45-11.37}$ & $\overline{1.22-12.03}$ & $\overline{5.23-8.03}$ & $\overline{5.48-6.18}$ & $\overline{-1.74-9.84}$ & $\overline{2.57-2.90}$ & $\overline{1.72-11.94}$ & $\overline{0.01-2.38}$ \\
\hline \multirow[b]{2}{*}{3} & \multirow{2}{*}{$\begin{array}{l}\text { Yagan } \\
(56.599405, \\
53.339568) \\
\end{array}$} & $\underline{11.06 \pm 0.12}$ & $14.90 \pm 0.21$ & $\underline{5.82 \pm 0.65}$ & $\underline{7.98 \pm 0.57}$ & $9.98 \pm 0.14$ & $\underline{4.97 \pm 0.44}$ & $\underline{6.47 \pm 0.22}$ & $\underline{6.72 \pm 0.09}$ & $\underline{3.30 \pm 0.45}$ & $\underline{3.07 \pm 0.48}$ & $4.92 \pm 0.07$ & $\underline{0.85 \pm 0.22}$ \\
\hline & & $\overline{10.53-11.58}$ & $\overline{13.99-15.81}$ & $\overline{3.02-8.62}$ & $\overline{5.52-10.44}$ & $\overline{9.38-10.59}$ & $\overline{3.08-6.85}$ & $\overline{5.50-7.45}$ & $\overline{6.31-7.13}$ & $\overline{1.35-5.25}$ & $\overline{1.00-5.14}$ & $\overline{4.62-5.22}$ & $\overline{-0.08-1.77}$ \\
\hline & \multirow{2}{*}{$\begin{array}{l}\text { Yagan } \\
(56.589050, \\
52.941519)\end{array}$} & $\underline{11.57 \pm 0.16}$ & $\underline{14.48 \pm 2.64}$ & $\underline{9.90 \pm 1.74}$ & $\underline{6.41 \pm 0.09}$ & $\underline{10.60 \pm 2.33}$ & $\underline{3.34 \pm 0.65}$ & $\underline{5.161 \pm 0.73}$ & $\underline{7.78 \pm 1.85}$ & $\underline{2.45 \pm 0.31}$ & $\underline{5.16 \pm 0.07}$ & $\underline{3.89 \pm 0.44}$ & $\underline{2.28 \pm 0.41}$ \\
\hline & & $10.87-12.27$ & $3.10-25.87$ & $2.43-17.38$ & $6.02-6.80$ & $0.58-20.62$ & $0.57-6.11$ & $4.84-5.47$ & $-0.19-5.74$ & $1.13-.3 .78$ & $4.85-5.47$ & $2.01-5.76$ & $0.52-4.05$ \\
\hline
\end{tabular}

Note. Above the line there is an average indicator value \pm the error of the mean $(\mathrm{m})$, below the line there is the confidence interval of the average value at a confidence level $\mathrm{p}=0.05$. 


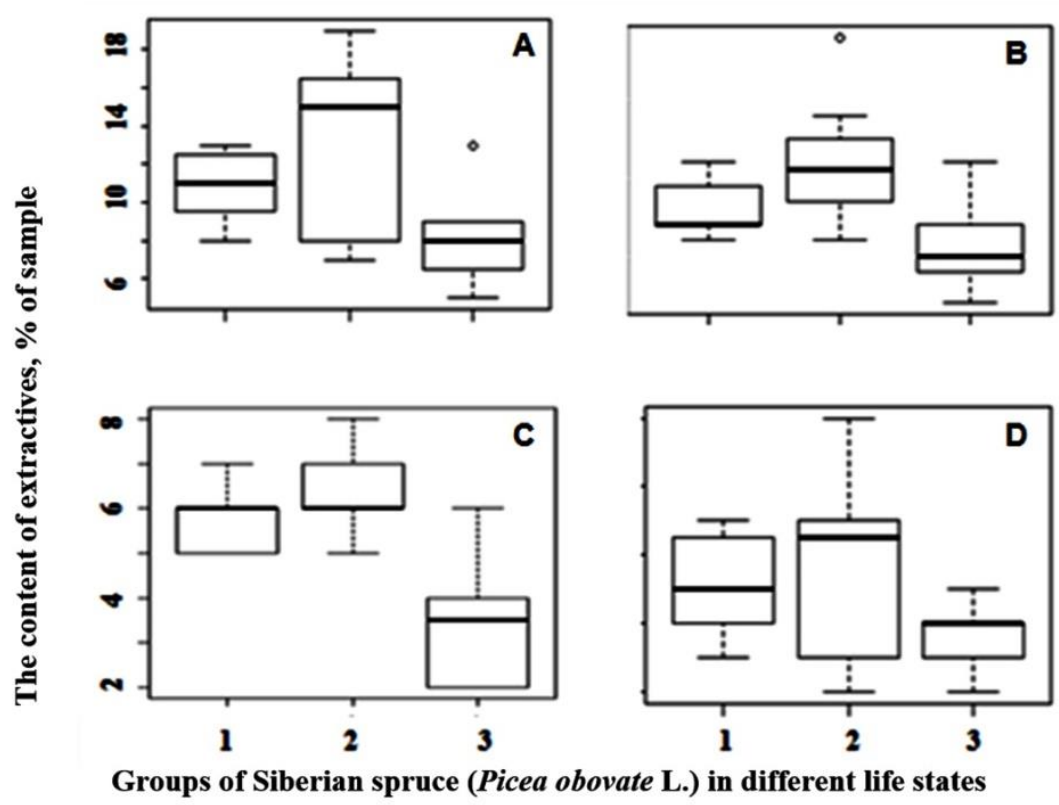

Figure 2. The content of various groups of extractives in Siberian spruce (Picea obovata L.) at different life states: A is the total content of extractives; $\mathrm{B}$ is water-soluble extractives; $\mathrm{C}$ is tannins; $\mathrm{D}$ is resinous extractives. Designations: 1- good vitality; 2- satisfactory; 3 - unsatisfactory
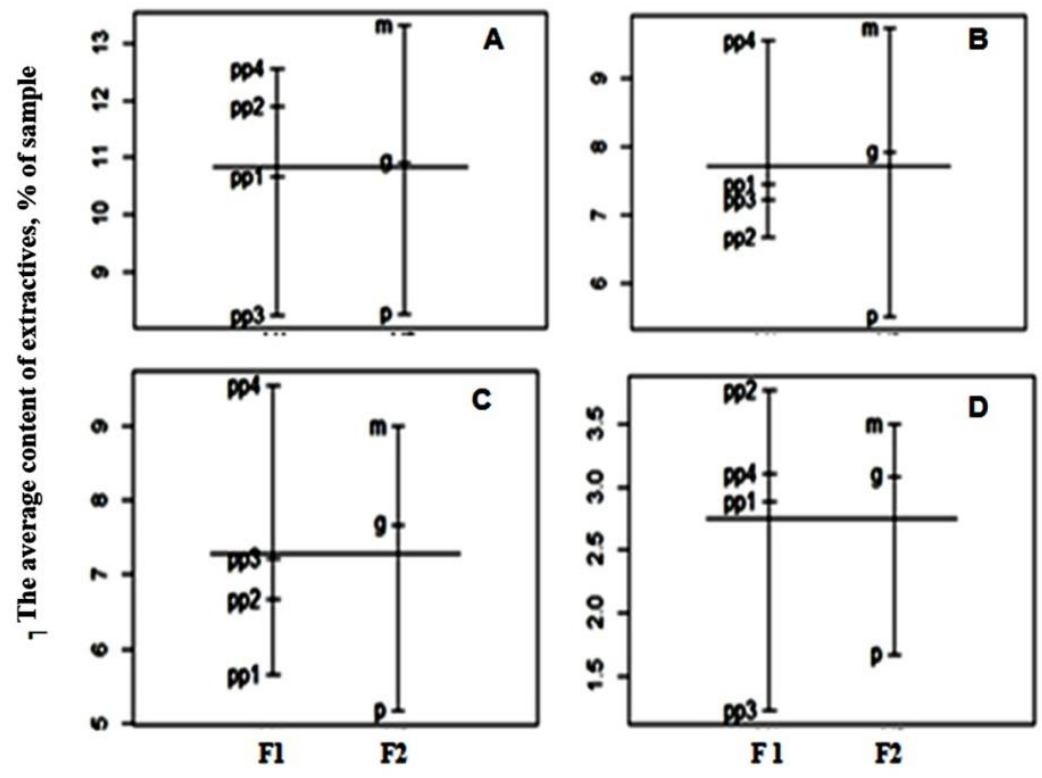

Figure 3. The average content of various groups of extractives in Siberian spruce (Picea obovata L.) in relation to various factors: A is total content of extractives; $\mathrm{B}$ is water-soluble extractives; $\mathrm{C}$ is tannins; $\mathrm{D}$ is resinous extractives. Designations: $\mathrm{V}_{1}$ - test plot (TP): tp1 - TP1, tp2 - TP2, tp3 - TP3, tp4 - TP4. $\mathrm{V}_{2}$ - vitality: g - good vitality; $\mathrm{m}$ - satisfactory vitality; $\mathrm{p}$ - unsatisfactory vitality 


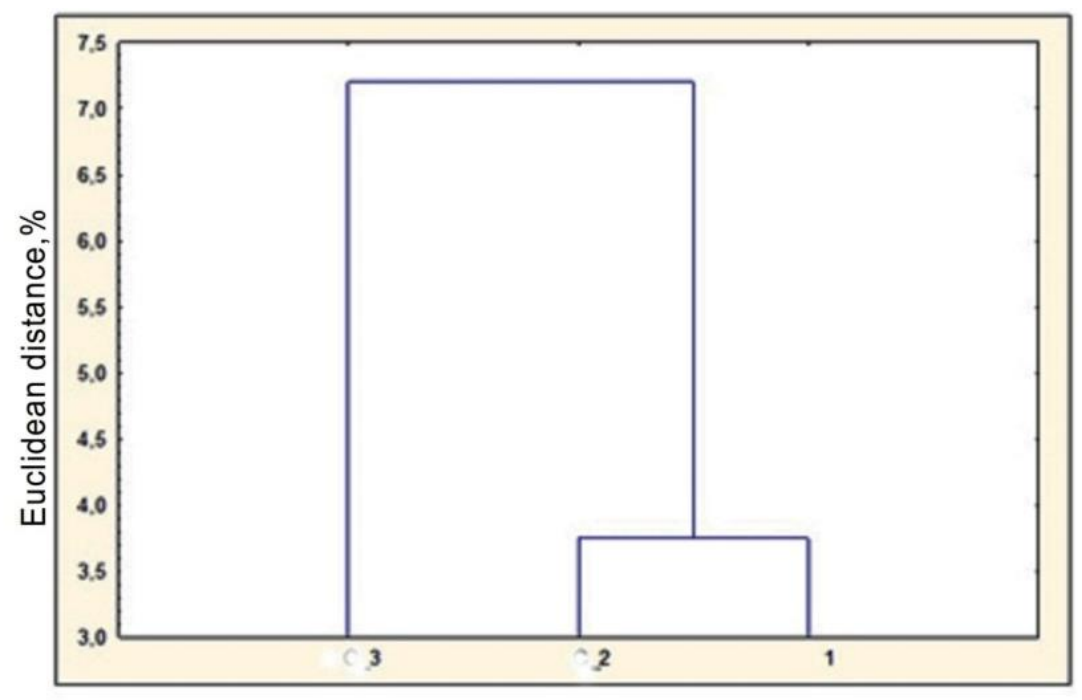

Figure 4. The results of the cluster analysis, the vital status of individuals by biochemical parameters 1- good vitality; 2- satisfactory; 3 - unsatisfactory

\section{Discussion}

The unfavorable state of dark coniferous plantations on the territory of the studied region is due to an unfavorable phytopathogenic background formed on the background of weakening of spruce plantations after abnormally high temperatures in 2010. However, despite the subsequent favorable climatic factors, the tendency for the state of spruce forests to deteriorate continues. This phenomenon is due to global processes taking place in the planet's atmosphere (Kennel \& Yulaeva, 2020). In Udmurtia, according to hydrometeorological observations for the period from 2006 to 2015, the total amount of precipitation during the growing season decreased, while the air temperature increased (average by $1.2{ }^{\circ} \mathrm{C}$ ) (Government of the Udmurt Republic, 2019). Similar climatic changes negatively affect photosynthetic potential Picea obovata, lowering their immune system. On the other hand, a shift in temperature towards an increase favorably affects the amplitude of development of insects.

The death of spruce individuals being the dominules, as revealed by the analyzed TPs, resulted in change of the existing ecosystem. Deciduous plants replaced coniferous species. The change in the main canopy led to changes in environmental factors: humidity, light, temperature. The shift in abiotic factors influences the remaining spruce specimens in a negative way by weakening their immunity and increasing the risk of damage by xylophages. The abundant food resources and favorable weather conditions (favorable winters) allow Ips typographus to create several generations. With increase in population, bark beetles begin to populate healthy trees causing the death of all spruce individuals.

Negative effects from insects lead to mechanical damage to trees and reduce their resistance, which leads to an increase in the prevalence of infectious diseases, in particular various mycoses (Horst, 2013). A number of fungi-destructors were revealed in the samples studied by us, in particular Torula herbarum, Humicolagrisea, Engyodontium album. It is known that the listed pathogenic mycobiota disrupts the processes of photosynthesis of trees, reduces their productivity and longevity, and can also cause mass destruction of forests (Brasier \& Buck, 2001; Yang et al., 2017).

At the outcome of this research, it was revealed that the content of extractive substances very greatly and depend on the state of the plant. The highest values were recorded for individuals at a satisfactory state. At the same time, this group of plants showed a high variability of extractive substances in comparison with the plants at a good life state. Thus, as shown by the results 
of previous studies, the mass dying out of spruce stands is observed under conditions close to optimal, but at the same time, in areas where spruce grows at the limit of its capabilities, its mass death was not observed (Heldt, 2015; Zinov'eva et al., 2009). Nonetheless, as it would seem, the impact from extra stresses should have led to dying out of plantations. In support of this assumption, in the research paper by Kishenkov F.V. (1979) on the study of radial growth, it is stated that the leading trees differ not only by the higher growth but also by its smaller variation. In suppressed trees, the magnitude of temporal variation in values of all structural elements of the annual ring is 2.5 times higher. Greater variability in structural elements of the annual ring may well reflect the variation in physiological and biochemical parameters.

Any living organism, including plants, being the open systems possess defense mechanisms against adverse environmental factors. The production of biologically active compounds plays a decisive role in event of phytophagy damage (Bahtenko, 2008; Makeeva, 2017; Schofield et al., 1998). This is also proved by this research.

It should be noted that, according to the published data, extractive substances inhibited in the cell wall have the greatest protective effect in comparison with substances from the intercellular space (Hillis, 1987; Kleist \& Schmitt, 1999; Srinivasan et al., 1999). However, the results of our study show that under the influence of wood pests in plants, not only tannins (extractive substances of the cell wall), but also substances formed outside the cell (resin) begin to be more actively produced.

\section{Conclusion}

The global processes taking place in the planet's atmosphere have already affected the original coniferous forests of the Udmurt Republic. The spruce stands get weaker, and are exposed to diseases and damage through the pathogenic organisms and insect pests. Over the past seven years, the extensive development of Ips typographus in the Udmurt Republic resulted in reduction in area of spruce forest stands by $8 \%$. A particularly difficult situation is witnessed in the south of the Republic, where the reduction in area of the spruce stands reached $15 \%$ and in certain forestries reaching even $25-50 \%$ (Government of the Udmurt Republic, 2019). The degradation of spruce forests resulted in change of succession stages from the dark coniferous forests to the soft-leaved ones. Consequently, the exposure to xylophages contributed to the decrease in resistance in trees and the opposite increase in spread of the destroying fungi, particularly represented by Torulaherbarum, Humicolagrisea, and Engyodontiumalbum.

One of the mechanisms of the plant defense response under the aggregated stress factors (inclusive of the damage caused by pathogenic organisms) is the synthesis of internal metabolites performing protective functions, such as increase in synthesis of extractive substances.

The content of extractive substances and their components varies greatly from one test plot to another. Their synthesis is undoubtedly associated with a particular state of the individuals, the degradation stage of forest stand, and peculiarities of the microand mesoclimatic conditions of the habitat. Nevertheless, the research study described herein revealed a similar trend for all surveyed areas. In trees at a satisfactory life state, the content of all components of extractive substances is higher in comparison with the individuals at other life states. This feature may indicate that the individuals in this category experience some negative impact presupposed by their weakening, and they cannot use these substances for protective purposes. At the same time, the variability of biochemical parameters in plants at a satisfactory state may be representative of a more dynamic defense response. In order to understand in depth the comprehensive action of extractives in defense response of spruce against bark beetles, we are conducting more extensive research by securing the new test plots not only in the subboreal zone, but also in the taiga zone of the Republic.

\section{Acknowledgements}

The work was carried out with the financial support of the RFBR grant 19-04-00353. 


\section{References}

Alyab'ev, A.F. (2013). Drying of spruce forests near Moscow. Vestnik MGUL Forest Herald, 6(98), 159-166.

Babkin, V.A. (2017). Extractive things of larch wood: Chemical composition, biological activity, prospects for practical use. Innovation and Expertise, 2(20), 210-223.

Bahshaliyeva, K.F. (2017). The ecolo-biological features of toxigenic fungi which spreads in Azerbaijan (Extended abstract of SD in Biology Dissertation). Retrieved from http://www.aak.gov.az/avtoref_to_mudaf/pdf_ to_mudaf/bio/bio_d_bkf_30_10_17.pdf

Bahtenko, E.Yu. (2008). The variety of secondary metabolites of higher plants. Vologda: VGPU.

Brasier, C. \& Buck, K. (2001). Rapid evolutionary changes in a globally invading fungal pathogen (Dutch elm disease). Biological Invasions, 3, 223-233.

Caudullo, G., Tinner, W. \& de Rigo, D. (2016). Piceaabies in Europe: Distribution, habitat, usage and threats. In J. San-Miguel-Ayanz (Ed.), European Atlas of Forest Tree Species, 114-116. Luxembourg: Publication Office of the European Union.

Fedorov, N.I. \& Sarnackij, V.V. (2005). Causal relationships of mass drying of spruce forests in Belarus in 1993-1998. Forest of the XXI century: Abstracts of the international practical conference. Bryansk: BSTU, 58;

Fedorova, T.E., Fedorov, S.V. \& Babkin, V.A. (2016). Oligolignans in the wood of Picea obovate Ledeb. Russian Journal of Bioorganic Chemistry, 42(7), 712-715.

Government of the Udmurt Republic. (2019). On approval of the Forest Plan of the Udmurt Republic (as amended on April 16, 2019), Decree of the Head of the Udmurt Republic of February 18, 2019 No. 17. Retrieved from http://docs.cntd.ru/document/553160573

Heldt, H.-W. (2015). Plant biochemistry. Moscow: Binom, LaboratorijaZnanij.

Hillis, W.E. (1987). Heartwood and tree exudates. Berlin-Heidelberg: Springer-Verlag.

Horst, R.K. (2013). Westcott's plant disease handbook (8th ed.). Dordrecht: Springer Netherlands.

Kennel, C.F. \& Yulaeva, E. (2020). Influence of Arctic sea-ice variability on Pacific trade winds. Proceedings of the National Academy of Sciences, 117(6), 2824-2834.

Kirk, P.M., Cannon, P.F., Minter, D.W. \& Stalpers, J.A. (2008). Dictionary of the fungi (10th ed.). Wallingford, Oxon, UK: CABI.

Kishenkov, F.V. (1979). Variability and viability of trees in populations of common pine.
Forest geobotany and biology of woody plants. Tula, 48-52.

Kleist, G. \& Schmitt, U. (1999). Evidence of accessory compounds in vessel walls of Sapelli heartwood (Entandrophragmacylindricum) obtained by transmission electron microscopy. HolzAlsRoh- Und Werkstoff, 57(2), 93-95.

Kunert, N. (2020). Preliminary indications for diverging heat and drought sensitivities in Norway spruce and Scots pine in Central Europe. iForest - Biogeosciences and Forestry, 13(2), 89-91. doi: https://doi.org/10.3832/ifor3216-012

Lakin, G.F. (1990). Biometrics: A textbook for biological specialties of universities (4th ed.). Moscow: Higher School.

Leontovyc, R. \& Kunca, A. (2006). The role of fungal pathogens in the premature decay of Norway spruce stands in Slovakia. Current problems of forest protection in spruce stands under conversion. Warsaw, Forest Research Institute, 79-84.

Makeeva, I.Yu. (2017). Physiological and biochemical responses Solanuttuberosomal action of caffeic acid ( $\mathrm{PhD}$ Thesis). Orel State University named after I.S. Turgenev, Orel, Russia.

Maslov, A.D. (2010). Printing bark beetle and drying of spruce forests. Moscow: VNIILM.

Mastickij, S.E. (2015). Statistical analysis and visualization of relatives using R. Retrieved from: https://www.ozon.ru/context/detail/id/3 3061125/

Negrón, J. (2018). Biological aspects of mountain Pine Beetle in Lodgepole pine stands of different densities in Colorado, USA. Forests, 10(1), 18.

Obolenskaya, A.V., El'nickaya, Z.P. \& Leonovich, A.A. (1991). Laboratory work on the chemistry of wood and cellulose: A manual for universities. Moscow: Ecology.

Rysin, I.I. (Ed.). (2009). Geography of Udmurtia: Natural conditions and resources: A training manual. Izhevsk: Izdatel'skiydom "Udmurtskiyuniversitet".

Scheffer, T.C. \& Cowling, E.B. (1966). Natural resistance of wood to microbial deterioration. Annual Review of Phytopathology, 147-168.

Scheffer, T.C., Morrell, J.J., \& Oregon State University, Forest Research Laboratory. (1998). Natural durability of wood: A worldwide checklist of species [Technical Report]. Retrieved from Corvallis, Or.: College of Forestry, Forest Research Laboratory, Oregon State University website: http://hdl.handle.net/1957/7736 
Schofield, J.A., Hagerman, A.E. \& Harold, A. (1998). Loss of tannins and other phenolics from willow leaf litter. Journal of Chemical Ecology, 24(8), 1409-1421.

Srinivasan, U., Ung, T., Taylor, A. \& Cooper, P.A. (1999). Natural durability and waterborne preservative treatability of tamarack. Forest Products Journal, 49(1), 8287. Retrieved from http://agris.fao.org/agrissearch/search.do?recordID=US201302914298

Sutton, D., Fothergill, A. \& Rinaldi, M. (2001). The Determinant of pathogenic and conditionally pathogenic fungi (transl. from Eng.). Moscow: World.

TAPPI. (1993). 1\% NaOH soluble (\%) T 212 om-93.

Tuffen, M.G. \& Grogan, H.M. (2019). The island of Ireland is free of many of the most damaging pests and diseases of spruce present in Europe, and consequently forest stands of Sitka spruce are generally healthy and productive Forestry. An International Journal of Forest Research, 92(1), 26-41. doi:10.1093/forestry/cpy036

Yang, J., Hsiang, T., Bhadauria, V., Chen, X.-L. \& Li, G. (2017). Plant Fungal Pathogenesis. BioMed Research International, 2017, 1-2.

Zhigunov, A.V., Semakova, T.A. \& Shabunin, D.A. (2007). Mass desiccation of forests in the North-West of Russia. Materials of the scientific conference dedicated to the 50th anniversary of the forest Institute of the Karelian scientific center of the Russian Academy of Sciences. Petrozavodsk: KarNC RAN, 42-52.

Zinov'eva, S.V., Vasyukova, N.I., Udalova, Zh.V., Gerasimova, N.G. \& Ozereckovskaya, O.L. (2009). The participation of salicylic acid in the resistance of plants to parasitic nematodes. Materials of the reports of the VI International Symposium on Phenolic Compounds: Fundamental Aspects, 99-100. 